\title{
Newborn hearing screening results in an inner part of Aegean region
}

\author{
İç Ege Bölgesi'ndeki yenidoğan işitme tarama testi sonuçları \\ İsa Özbay', Cüneyt Kucur', Fatih Oğhan', Sinan Aksoy', Onur Erdoğan', Yasin Tuğrul Karakuş² \\ ${ }^{1}$ Department of Otorbinolaryngology, Faculty of Medicine, Dumlupinar University, Kütahya, Turkey \\ ${ }^{2}$ Department of Pediatrics, Faculty of Medicine, Dumlupınar University, Kïtabya, Turkey
}

\begin{abstract}
Objective: To investigate hearing loss ratio of babies screened at our university hospital which is reference hospital in Kütahya, Turkey.

Methods: A total number of 6881 newborns were screened for hearing between February 2010 and December 2013 in our hospital. Screening was done before newborns discharged. The parents of the newborns discharged during holidays were asked to come within 15 days. A three-stage screening protocol was implemented consisting of an initial screening with transient evoked otoacoustic emissions (TEOAE) followed by a second-stage screening also with TEOAE and screening auditory brainstem response (ABR). Babies who had unilateral or bilateral referrals with TEOAE and screening ABR were referred to other clinics which have clinical ABR. Babies were divided into 2 groups by means of having risk factors and not having risk factors.

Results: Out of 6881 newborns, $33(0.47 \%)$ of them had hearing loss consisting of $21(0.3 \%)$ patients had bilateral hearing loss and 12 $(0.17 \%)$ patients had unilateral hearing loss.

Conclusion: Newborn hearing screening tests should be done throughout the country and the babies with hearing loss should be identified before permanent damages occur so that these patients can be productive people for society.
\end{abstract}

Keywords: Hearing loss, otoacoustic emission, auditory brainstem response, newborn.

The aim of the newborn screening is to identify infants with important hearing impairment in by means of the most rapid and cost effective way. The severity of hearing loss extends from mild sensory hearing loss to severe, even total sensory hearing loss. The early detection of hearing

\section{Özet}

Amaç: Çalışmamızın amacı Türkiye'nin Kütahya ilinde referans hastanesi olan üniversite hastanemizde bebeklerdeki işitme kaybı oranını araştırmaktır.

Yöntem: Hastanemizde Şubat 2010 ile Aralık 2013 tarihleri arasında 6881 yenidoğan, tarama testlerinden geçirilmiştir. Tarama testleri bebekler taburcu edilmeden yapılmış ve 15 gün içinde bebeklerin yeniden getirilmeleri söylenmiştir. Bebekler tatilde iken taburcu edilmişlerse 15 gün içinde getirilmeleri söylenmiştir. Başlangıçta geçici olarak uyarılmış otoakustik emisyonlar (TEOAE) daha sonra ikinci evrede TEOAE ile işitsel beyinsapı yanıt (ABR) testlerinden ibaret üç aşamalı bir tarama protokolü uygulanmıştır. TEOAE ve ABR tarama tesleriyle tek veya çift taraflı işitme kayıpları olan bebekler klinik ABR olanağı bulunan başka kliniklere yollanmıştır. Bebekler risk faktörleri olanlar ve olmayanlar olmak üzere iki gruba ayrılmıştır.

Bulgular: Toplam 6681 yenidoğanın 33'ünde (\%0.47) işitme kaybı mevcuttu. İşitme kayıpları çift $(\mathrm{n}=12 ; \% 0.3)$ veya tek $(\mathrm{n}=12 ; \% 0.17)$ taraflı idi.

Sonuç: Yenidoğanlarda işitme tarama testleri yurt çapında yapılmalı, bu hastaların toplum için üretken olabilmeleri amacıyla kalıcı hasarlar oluşmadan önce saptanmalıdır.

Anahtar sözcükler: İşitme kaybı, otoakustik emisyon, işitsel beyinsap1 yanıtı, yenidoğan.

loss is very important because hearing loss in childhood is a condition that may adversely affect cognitive, emotional and social development of an individual. ${ }^{[1]}$ It also causes a decrease in the intellectual ability and deterioration of socioeconomic status of the person. ${ }^{[2]}$ Infants whose hear-
Correspondence: İsa Özbay, MD. Department of Otorhinolaryngology, Faculty of Medicine, Dumlupınar University, Kütahya, Turkey.

e-mail: isaozbay@yahoo.com

Received: November 2, 2014; Accepted: December 2, 2014
Online available at: www.jmedupdates.org doi:10.2399/jmu.2014003009 QR code: 
ing loss is identified before 6 months of age have significantly better language abilities compared to those whose hearing loss were identified after 6 months. ${ }^{[3,4]}$ Therefore, newborn hearing screening, which is considered to be an effective procedure in early detection of hearing impairment, should be one of the priorities in neonatal care units. $^{[5]}$

The techniques most often employed in neonatal hearing screens are evoked otoacoustic emissions (EOAE) and automated auditory brainstem response (ABR). EOAE is a noninvasive and quick technique. There are two types of EOAE, mostly used in the newborn hearing screening namely transient evoked otoacoustic emissions (TEOAE) and distortion product otoacoustic emissions (DPOAE). TEOAE is preferred rather than DPOAE for the newborn hearing screening because it is applied in a shorter time, it is more easy to perform and more sensitive for mild degree hearing impairment. ${ }^{[6,7]}$ Auditory brainstem response is an auditory evoked potential that originates from the auditory nerve. ABR can detect damage to the cochlea, the auditory nerve and the auditory pathways in the stem of the brain.

The aim of this study is to evaluate the results of newborn hearing screening by means of TEOAE and ABR in Kütahya district of Turkey.

\section{Materials and Methods}

A total number of 6881 newborns, who were born in our hospital or admitted to our hospital from other health care centers, were screened for their hearing acuity between February 2010 and December 2012 at our university. Screening was done before newborns discharged. All babies who were born in our hospital underwent TEOAE within 10 days after birth. Newborns hearing screening tests were performed while the babies were sleeping or motionless. The screening was conducted by two qualified audiologists using TEOAE. Bilateral pass was considered as criteria for passing.

A three-stage screening protocol was implemented consisting of an initial screening with TEOAE followed by a second-stage screening also with TEOAE 1 or 2 weeks later. If a baby did not pass the second-stage screen, he/she was evaluated for diagnostic testing. This diagnostic evaluation was included ear nose and throat examination by otorhinolaryngologist, tympanometry and screening ABR. Inflammation in the middle ear, external ear or debris in the external ear canal was treated. Babies with unilateral or bilateral referrals with TEOAE and screening ABR were referred to other clinics, which have clinical ABR facilities.

Babies were divided into 2 groups as those with or without risk factors (Table 1). TEOAE and screening ABR tests were performed concurrently on the babies who were considered at high risk for permanent congenital hearing loss.

\section{Results}

A total number of 6881 babies screened using TEOAE and screening ABR between 2010 and 2012 years. All babies screened with first stage TEOAE. Eight hundred and thirty-six babies (12.14\%) who had unilateral and bilateral referrals with first stage TEOAE, were screened by second stage with TEOAE. After second screening stage with TEOAE, 69 babies had referrals. Sixty nine babies had $(\mathrm{n}=41)$ or had not $(\mathrm{n}=28)$ risk factors.

Among 28 babies, who had not any risk factors, 21 of them had bilateral referrals with second stage TEOAE; 7 of them had unilateral referrals with second stage TEOAE and screening ABR. These 21 babies underwent screening ABR and 15 of them had bilateral referrals, one of them passed unilaterally with screening ABR and five of them passed bilaterally with screening ABR.

Among 41 babies, who had risk factors, 33 of them had bilateral or unilateral referrals with second stage TEOAE and screening ABR; 8 babies had bilateral referrals with second stage TEOAE but passed bilaterally with screening ABR. Thirty-two babies who had unilateral or bilateral referrals with TEOAE and screening ABR were referred to other clinics which has clinical ABR and 22 babies passed with clinical ABR. One baby died before going to

Table 1. Risk factors for hearing impairment.

1. Familial hearing loss

2. In utero infections (TORCH)

3. Craniofacial anomalies

4. Low birth weight (lower than $1500 \mathrm{~g}$ )

5. Hyperbilirubinemia

6. Bacterial menengitis

7. Ototoxic drug usage

8. Apgar score lower than 4 in one minute and lower than 6 in 5 minutes

9. Mechanic ventilation more than 10 days

10. Syndromes related with sensorineural or conductive hearing loss

TORCH: Toxoplasmosis, Rubella, Cytomegalovirus, Herpes simplex 
Table 2. Results of newborn hearing screening of babies with risk factors.

\begin{tabular}{lccccc}
\hline & 1st TEOAE & 2nd TEOAE & Screening ABR & Clinical ABR \\
\hline \multirow{2}{*}{ Passed } & & 64 & 0 & 8 & 22 \\
\hline \multirow{2}{*}{ Referred } & Unilateral & $10(9.5 \%)$ & $10(9.5 \%)$ & $10(9.5 \%)$ & $4(3.80 \%)$ \\
& Bilateral & $31(29.5 \%)$ & $31(29.5 \%)$ & $23(21.09 \%)$ & $6(5.71 \%)$ \\
& Total & $41(39.04 \%)$ & $41(39.04 \%)$ & $33(31.42 \%)$ & $10(9.52 \%)$ \\
\hline Total & 105 & 41 & 41 & $32 *$ \\
\hline
\end{tabular}

*One baby died before being transferred to other clinics.

another clinic. Overall, 10 babies had final referrals among babies with risk factors (Table 2).

Finally, out of 6881 newborns, 33 (0.47\%) of them had hearing loss consisting of $21(0.3 \%)$ patients had bilateral hearing loss and $12(0.17 \%)$ patients had unilateral hearing loss (Table 3).

\section{Discussion}

Newborn hearing screening program is now in widespread use in all institution ${ }^{[8]}$ and it is the only program which detect the babies with hearing loss at its earlier stage. Definite diagnosis of the hearing impairment within the first 3 months of life and beginning therapy after 6 months increases the possibility of appropriate speech and language development and reduces neurodevelopmental problems. ${ }^{[9,10]}$ If newborn hearing screening is done with only babies who have risk factors, we only detect half of babies with hearing impairment. ${ }^{[1]}$ Therefore widespread usage of newborn hearing screening is crucial.

Although bilateral pass is considered as normal in most of the hearing screening protocols, some studies consider unilateral pass as normal hearing. ${ }^{[12,13]}$ But, if unilateral hearing is considered as normal, hearing impairment of the other ear may be overlooked. Therefore, in the present study, we considered bilateral pass as normal hearing.
TEOAE and ABR are generally used in newborn hearing screening. TEOAE is non-invasive, easily applicable, timesparing, cheap and sensitive method. ${ }^{[14]}$ If baby passes TEOAE bilaterally, this means that baby has normal functions of outer hair cells and his /her hearing loss is not more than $40 \mathrm{~dB} \cdot{ }^{[1,15]} \mathrm{ABR}$ indicates electrical activity of brainstem hearing system which is not affected by cerumen and otitis media with effusion. ${ }^{[16]} \mathrm{ABR}$ is a noninvasive test and performed on sleeping or awake baby under general anaesthesia. ${ }^{[17]}$

There are different protocols for newborn hearing screening in the literature. The most common program used for newborn hearing screening is triple screening $\operatorname{program}^{[18,19]}$ which means application of 2 times TEOAE and 1 time screening ABR. In the present study, triple screening program was also used and bilateral hearing was considered as passed. There are some studies which considered unilateral hearing as passed $\mathrm{d}^{[12,19]}$ but we thought that if we consider unilateral hearing as passed, we may ignore the hearing disorders of the contralateral ear.

Babies were grouped as healthy babies and babies monitored in intensive care units (ICUs). Some studies have only accepted healthy babies, while others included babies in the ICU in their screening program. ${ }^{[12,13.17]}$ We accepted all of the babies for newborn hearing screening program because we wanted to detect the prevalence of hearing loss in Kutahya, Turkey. To the best of our knowledge this is

Table 3. Results of newborn hearing screening.

\begin{tabular}{lccccc}
\hline & 1st TEOAE & 2nd TEOAE & Screening ABR & Clinical ABR \\
\hline Passed & & 6812 & 767 & 13 & 22 \\
\hline Referred & Unilateral & $221(3.21 \%)$ & $17(0.24 \%)$ & $18(0.26 \%)$ & $12(0.17 \%)$ \\
& Bilateral & $615(8.93 \%)$ & $52(0.76 \%)$ & $38(0.55 \%)$ & $21(0.30 \%)$ \\
& Total & $836(12.14 \%)$ & $69(1.01 \%)$ & $56(0.81 \%)$ & $33(0.47 \%)$ \\
\hline Total & & 6881 & 836 & 69 & 55 \\
\hline
\end{tabular}


the first study in the literature evaluating prevalence of hearing loss in Kütahya, Turkey.

In the present study, out of 6881 newborns, $33(0.47 \%)$ of them had bilateral $(n=21 ; 0.30 \%)$ or unilateral $(n=12$; $0.17 \%$ ) hearing loss. In the international literature, incidence of congenital hearing loss changes between 0.13 and $0.60 \% \cdot{ }^{[13,20,21]}$ In national literature, incidences of hearing loss among newborns differed widely (Kayiran et al., $0.22 \%$ of 8052 newborns; ${ }^{[2]}$ Genc et al., 0.2 in 5485 newborns; ${ }^{[23]}$ Tatli et al., 0.28 in 711 newborns $^{[24]}$ and Kucur et al., 0.15 in 11053 newborns. $\left.{ }^{[25]}\right)$. In the present study, although the ratio is a little higher than ratios of those cited in the national literature, it can be accepted in accordance with national and international literature. Martin et al., found the incidence of hearing loss as $10 \%$. Since they include only babies with risk factors, this high incidence rate was normal for their risky study population. ${ }^{[2]}$ In our study, out of 105 babies who had risk factors, we found the frequency of hearing loss as $9.5 \%$ which was compatible with the literature data.

For babies who were not screened for hearing loss, diagnosis of hearing loss can be delayed up to 3 years. ${ }^{[27]}$ If amplification could be performed between 6-12 months of age, the patients might have the same speech and cognitive function with healthy children ${ }^{[28]}$ Otherwise, psychosocial development of the patient will be delayed and patient will lag behind their peers regarding education and social compatibility. Therefore, these patients will have not only hearing loss, but also they will have psychological disorders and as a result they will be incompatible with social life. They will not be productive people for society, and they will need support by government.

As a conclusion, if hearing loss is not diagnosed earlier, it impairs speech and language development. Newborn hearing screening tests should be done throughout the country and the babies with hearing loss should be identified before permanent damages occur so that these patients can be productive people for society.

Conflict of Interest: No conflicts declared.

\section{References}

1. Korres S, Balatsouras DG, Vlachou S, Kastanioudakis IG, Ziavra NV, Ferekidis E. Overcoming difficulties in implementing a universal newborn hearing screening program Turk J Pediatr 2005; 47:203-12.

2. Walch C, Anderhuber W, Köle W, Berghold A. Bilateral sensorineural hearing disorders in children: etiology of deafness and evaluation of hearing tests, Int J Pediatr Otorhinolaryngol 2000; $53: 31-8$.
3. Calderon R, Naidu S. Further support of the benefits of early identification and intervention with children with hearing loss. Volta Rev 2000;100:53-84.

4. Moeller MP. Early intervention and language development in children who are deaf and hard of hearing, Pediatrics 2000;106: $1-9$.

5. Hess M, Finckh-Krämer U, Bartsch M, Kewitz G, Versmold H, Gross M. Hearing screening in at-risk neonatecohort. Int J Pediatr Otorhinolaryngol 1998;46:81-9.

6. Kemp DT, Ryan S, Bray P. A guide to effective use of otoacoustic emissions. Ear Hear 1990;11:93-105.

7. White KR, Vohr BR, Behren TR. Universal newborn hearing screening using transient evoked otoacoustic emissions: results of Rhode Island Hearing Assessment Project. Semin Hear 1993;14: 18-29.

8. Kountakis SE, Psifidis A, Chang CJ, Stiernberg CM. Risk factors associated with hearing loss in neonates. Am J Otolaryngol 1997: $18 ; 90-3$.

9. Yoon PJ, Price M, Gallagher K, Fleisher BE, Messner AH. The need for long-term audiologic follow-up of neonatal intensive care unit (NICU) graduates. Int J Pediatr Otorhinolaryngol 2003:67; $353-7$.

10. Kountakis SE, Skoulas I, Phillips D, Chang CY. Risk factors for hearing loss in neonates: a prospective study. Am J Otolaryngol 2002;23:133-7.

11. American Academy of Pediatrics. Task Force on Newborn and Infant Hearing. Newborn and infant hearing loss: detection and intervention. Pediatrics 1999;103:527-30.

12. Thornton AR, Kimm L, Kennedy CR. Methodological factors involved in neonatal screening using transientevoked otoacoustic emissions and automated auditory brainstem response testing. Hear Res 2003;182:65-76.

13. Lin CY, Huang CY, Lin CY, Lin YH, Wu JL. Community based newborn hearing screening program in Taiwan. Int J Pediatr Otorhinolaryngol 2004;68:185-9.

14. Paludetti G, Ottaviani F, Fetoni AR, Zuppa AA, Tortorolo G. Transient evoked otoacoustic emissions (TEOAEs) in newborns: normative data. Int J Pediatr Otorhinolaryngol 1999;47:235-41.

15. Kemp DT, Ryan S, Bray P. A guide to effective use of otoacoustic emissions. Ear Hear 1990;11:93-105.

16. Hahn M, Lamprecht-Dinnesen A, Heinecke A, et al. Hearing screening in healthy newborns: feasibility of different methods with regard to test time. Int J Pediatr Otorhinolaryngol 1999;51: 83-9.

17. Kennedy CR, Kimm L, Dees DC, et al. Otoacoustic emissions and auditory brainstem responses in the newborn. Arch Dis Child 1991;66:1124-9.

18. Hatzopoulos S, Pelosi G, Petruccelli J, et al. Efficient otoacoustic emission protocols employed in a hospitalbased neonatal screening program. Acta Otolaryngol 2001;121:269-73.

19. Jakubikova J, Kabatova Z, Zavodna M. Identification of hearing loss in newborns by transient otoacoustic emissions. Int J Pediatr Otorhinolaryngol 2003;67:15-8.

20. Cox LC, Toro MR. Evolution of a universal infant hearing screening program in an inner city hospital. Int J Pediatr Otorhinolaryngol 2001;59:99-104. 
21. Szyfter W, Wróbel M, Radziszewska-Konopka M, Szyfter-Harris J, Karlik M. Polish universal neonatal hearing screening program4-year experience (2003-2006). Int J Pediatr Otorhinolaryngol 2008;72:1783-7.

22. Kayıran SM, Genç E, Erdil A, Gürakan BA. Results of American Hospital newborn hearing screening program. [Article in Turkish] Türk Pediatri Arşivi 2009;44:135-7.

23. Genç GA, Başar F, Kayıkçı ME, et al. Newborn hearing screening outcomes in Hacettepe University. [Article in Turkish] Çocuk Sağlığı ve Hastalıkları Dergisi 2005;48:119-24.

24. Tatli MM, Serbetcioglu MB, Duman N, et al. Feasibility of neonatal hearing screening program with two-stage transient otoacoustic emissions in Turkey. Pediatr Int 2007;49:161-6.
25. Kucur C, Kınış V, Özdem Ş, Kucur SK. Newborn hearing screening results at Zeynep Kamil Women and Children Diseases Education and Research Hospital. [Article in Turkish] Kulak Burun Bogaz Ihtis Derg 2012;22:38-42.

26. Martin WH, Schwegler JW, Gleeson AL, Shi YB. New techniques of hearing assessment. Otolaryngol Clin North Am 1994; 27:487-510.

27. Center for disease control and prevention (CDC). Serious hearing impairment among children aged 3-10 years. Atlanta, Georgia, 1991-1993. MMWR Morb Mortal Wkly Rep 1997;46:1073-6.

28. Yoshinaga-Itano C, Sedey AL, Coulter DK, Mehl AL. Language of early- and later-identified children with hearing loss. Pediatrics 1998;102:1161-71.

This is an open access article distributed under the terms of the Creative Commons Attribution-NonCommercial-NoDerivs 3.0 Unported (CC BYNC-ND3.0) Licence (http://creativecommons.org/licenses/by-nc-nd/3.0/) which permits unrestricted noncommercial use, distribution, and reproduction in any medium, provided the original work is properly cited.

Please cite this article as: Özbay İ, Kucur C, Oğhan F, Aksoy S, Erdoğan O, Karakuş YT. Newborn hearing screening results in an inner part of Aegean region. J Med Updates 2014;4(3):105-109. 